\title{
Relationship between Working Capital and Corporate Performance in the Textile Sector of Pakistan
}

\author{
Shahzad Atta ${ }^{1}$, Haris Javed ${ }^{1}$, Muhammad Jawad Khalil ${ }^{1}$, Imtiaz Ahmad ${ }^{2}$ and \\ Muhammad Nadeem ${ }^{3 *}$ \\ ${ }^{1}$ MS Scholar, National University of Modern Languages Islamabad, Pakistan \\ ${ }^{2}$ PHD Scholar, North China University of Water Resources and Electric Power \\ ${ }^{3}$ Faculty of Management Sciences, National University of Modern Languages Multan
}

Received: October 21, 2017; Accepted: November 01, 2017; Published: November 09, 2017

*Corresponding author: Muhammad Nadeem, Faculty of Management Sciences, National University of Modern Languages Multan. E-mail:- muhammadnadeem19@gmail.com

\begin{abstract}
This research study has tried to examine the association between the working capital and corporate performance in the textile sector of Pakistan. Textile sector is one of the major sectors in Pakistan which have crucial contribution in the economy. Secondary data was gathered and used for the evaluation of the relationship between the working capital and corporate performance in the textile sector of Pakistan. Data was collected from the annual reports of the companies published during 2008-2012. Regression Model is used for the analysis of the gathered data. Results revealed that average collection period and operating cycle are positively associated with the corporate performance of the organizations in Pakistan. Corporate performance is measured through return on equity and firm size is positively associated with the return on equity. Leverage is negatively linked to the return on equity in the textile sector of Pakistan. Overall it has been observed that working capital and corporate performance are linked and have significant impact on the textile sector of Pakistan.

Keywords: Textile Sector, Working Capital, Corporate Performance, Profitability, Pakistan
\end{abstract}

\section{Introduction}

Working capital is related with managing and financing short term investment decisions and management of current assets as well as fixed assets at the same time. Managing theses short term investment decisions is known as working capital management. All the organizations manage their current assets efficiently due to their importance in the measurement of overall performance of the organizations. Productions organizations manage their current assets with great care due the dependence of their liquidity and profitability on the working capital. It is evident from the past researches that organizations have faced critical situations due to their mismanagement of working capital. All those organizations operating in developed or developing countries, which have given less importance to their working capital have suffered in managing ideal performance [1].
Liquidity of the organizations is as crucial as the profitability of the organizations. Balance between the liquidity and profitability is crucial to be managed due to their critical impact on the organizations. Literature has provided the risk of insolvency for those organizations which are failed to manage the balance between the liquidity and profitability of the organizations. Organizations with too much short term assets and the organizations with less than the required short term investment have faced serious risk of insolvency in the past therefore the balance between the current assets and long term assets is very crucial for the organizations [10].

Capital Budgeting, Capital Structure and Working Capital Management are the main roofs of finance which are crucial to be handled[4].Working capital management is related to the current asset management which directly affect the liquidity of the organizations. Capital Budgeting and Capital Structure are associated with the handling of long term assets which have more impact in the long run and return of the assets. Mostly studies have focused on the developed countries to measure the impact of working capital on the performance of the organization whereas less work has been done in the under developed countries. This research study has focused to evaluate the effect of working capital on the performance of the organization in the textile sector of Pakistan which is not focused in the past.

\section{Literature Review}

The significance of working capital management efficiency is undeniable. It is known as life giving force for any organization and its management is considered among the most essential functions of corporate management. Every organization whether, profit oriented or not, regardless of their size and nature of business, requires necessary and sufficient amount of working capital and its management. It is the most fundamental factor for maintaining liquidity, survival, solvency and profitability of business. 
Considering the importance of working capital management the researchers focused on evaluating the working capital management and profitability relationship among others. However, there are a few studies with reference to Pakistan like [2]. Working Capital Management is vital as it directly affects the profitability and liquidity of firms. Working capital management is one of the most essential areas while making the liquidity and profitability comparisons among firms involving the decision of the amount and composition of current assets and the financing of these assets. The greater the relative proportion of liquid assets, the smaller the risk of running out of cash, all other things being equal. All components of working capital including cash, marketable securities, account receivables and inventory management play a vital role in the performance of any firm. Efficient working capital management is very important to create value for the shareholders.

Corporate Performance is simply the performance of the corporation or company and Corporate Performance Management is the effective and efficient management of the corporation that leads them towards the achievement of their goals [5]. Here performance is considered and measured with the help of different indicators that include profitability and firm size etc. Budgeting, Forecasting and Planning are some components of corporate performance management that help corporations to observe and plan about the performance of the corporations from time to time.

Padachi observed the trends in Working Capital Management and its impact on the performance of firms [9]. Panel data analysis and regression analysis was used on a sample of 58 small manufacturing Mauritian firms for the period of 1998-2003. The dependent variable, return on total assets was used as a measure of profitability and the relation between working capital management and corporate profitability. The study revealed that paper and printing industry were having best practices due to efficient management of components of working capital and its positive impacts on profitability, thus they were considered industry champions.

Mathuva DM tested the influence of working capital management components on corporate profitability in Kenya [7]. A sample of 30 firms listed on the Nairobi stock exchange from 1993 to 2008 was used. Pooled OLS and fixed effect regression models were used. The study concluded that there exists a highly significant negative relationship between the time it take for firms to collect cash from their customers and profitability.

\section{Determinants of Profitability}

Determinants of Profitability are explored below to examine the relationship between the working capital and corporate performance in the textile sector of Pakistan.

\section{Average Collection Period}

Average collection period is the time period in which organizations collect their receivables from the customers. Organizations with the strict collection policy cannot survive in long time period but too much leniency in the collection duration may also affect the profitability of the organizations badly [6]. Some studies have found positive association of average collection period with profitability but according to some researches there is negative association between the average collection period and profitability of the organizations.

\section{Operating Cycle}

Operating cycle is a complete cycle in which organizations procure and convert the raw material into finished goods and receive the cash against the sold items. Normally it takes more time to receive the cash which affects negatively to the profitability but it can be improved through reducing no of days in receivables [8].

\section{Cash Conversion Cycle}

Cash conversion cycle is a time period in which organizations convert their resources into cash flows. Cash inflow and cash outflow are two have much importance in measuring the performance of the organizations [3]. Organizations expect a negative relationship between the cash conversion cycle and profitability of the organizations but some studies also found a positive relationship of cash conversion cycle with profitability.

On the basis of the above facts following hypothesis can be developed.

H1: There is positive and significant relationship between average collection period and ROE.

H2: There is positive and significant relationship between operating cycle and ROE.

H3: There is positive and significant relationship between cash conversion cycle and ROE.

\section{Research Methodology}

This study explores the determinants of corporate performance in context of textile firms of Pakistan. It is based on secondary data that is collected form annual reports of firms. These firms are listed on Karachi Stock exchange. The sample size is the data of 38 firms listed on Karachi stock exchange of Pakistan. The analysis is restricted to period of 5 years (2008-2012). Only those firms have been selected whose data was available for all these years. The appropriate sampling technique has been used as the data of as much firms was easily available that included in the sample. Regression analysis has been done in this study. Using regression model, each variable is being added to the model in view of its estimation power over the dependent variable. Each time as the variable enters into the model, all the other variables are reexamined and some variables restricted out in analysis due to negative values. Data for this research was collected from the concerned firm's websites, from company offices and from the website of Karachi stock exchange. Panel data is used for the purpose of evaluating the samples and to cater the dynamic situations. Return on equity is the dependent variable measured to evaluate the profitability of the organizations whereas the Average collection period, Cash conversion cycle and Operating cycle are the explanatory variables. This model was used before by Abuzayed [8]. 


$$
\begin{gathered}
\text { y_it }=\alpha+X \_ \text {it } \beta+\mu \_ \text {it } \\
i=1, \ldots \ldots \ldots \ldots \ldots \ldots . ., 38 ; t=1, \ldots \ldots . ., 5
\end{gathered}
$$

$i$ stands for the ith cross-sectional unit and $t$ for the th time period. $y_{i t}$ is performance measure $\left(R O E_{i t}\right)$ for the $i$ th firm at time $t$, and $\alpha$ is the intercept. $X_{i t}^{\prime}$ is a $1 \times \mathrm{x}$ vector of observations on $K$ explanatory variables for the ith firm in the $t$ th period $\beta$ is a $K \times 1$ vector of parameters, $u_{i t}$ is a disturbance term and is defined as

$$
u_{i t}=\mu_{i}+v_{i t}
$$

Where $\mu_{i}$ denotes the unobservable individual effects and $v_{i t}$ denotes the remainder disturbance. The descriptions of three estimation models (i.e., pooled OLS, fixed effects and random effects) can be written for each component of working capital as below.

$$
\begin{aligned}
& R O E_{i t}=\beta_{0}+\beta_{1} \mathrm{ACP}_{i t}+\beta_{2} \mathrm{LEV}_{i t}+\beta_{3} S I Z E_{i t}+\varepsilon_{i t} \\
& \mathrm{ROE}_{i t}=\beta_{0}+\beta_{1} O C_{i t}+\beta_{2} L E V_{i t}+\beta_{3} S I Z E_{i t}+\varepsilon_{i t} \\
& R O E_{i t}=\beta_{0}+\beta_{1} C C C_{i t}+\beta_{2} L E V_{i t}+\beta_{3} S I Z E_{i t}+\varepsilon_{i t}
\end{aligned}
$$

Where is the return on equity for the ith firm at the time $t$, is the average collection period of ith firm at time $t$, is the operating cycle of the ith firm at time $t$, is the cash conversion cycle of ith firm at time $t$.

\section{Findings}

[Table 1] It is obvious from the above results that average median and the return on equity are positive which 0.1354 is. Average median of the average collection period is positive with the return on equity which is 10.1649 . Average median of the operating cycle is positive with the return on equity which is 64.2921. Average median of the cash conversion cycle is negative with the return on equity which is -29.1482 . It is pertinent to mention that return on equity is measured as profit before taxation/ total shareholder equity. Average collection period

\begin{tabular}{|c|c|c|c|c|c|c|}
\hline Variables & Observations & Mean & Std. Dev & Median & Maximum & Minimum \\
\hline$R O E_{\text {it }}$ & 185 & 0.1528 & 0.2644 & 0.1354 & 1.2984 & -0.5149 \\
\hline$A C P_{\text {it }}$ & 185 & 17.4681 & 18.2482 & 10.1649 & 85.4827 & 0 \\
\hline$O C_{i t}$ & 185 & 81.4683 & 62.8746 & 64.2921 & 370.4917 & 0.1171 \\
\hline$c C C_{i t}$ & 185 & -121.4627 & 213.8462 & -29.1482 & 279.1548 & -934.5419 \\
\hline$S I Z E_{i t}$ & 185 & 14.7129 & 1.4789 & 14.1872 & 16.4731 & 8.4771 \\
\hline$L E V_{i t}$ & 185 & 0.364 & 0.1721 & 0.4978 & 0.8179 & 0.0049 \\
\hline
\end{tabular}
calculated as trade debts/ (sales/360). Cash conversion cycle (measured as [average age of inventory + average collection period)-average payment period]. Operating cycle (measured as average age of inventory + average collection period).

Table 1: Descriptive Statistics

[Table 2] According to results of the above results it is clear that return on equity has positive link and correlated with average collection period, firm size and cash conversion cycle while it is negatively linked and correlated with leverage and operating cycle. Average collection period has positive link and correlated with return on equity, leverage, cash conversion cycle and operating cycle while it is negatively linked with size of the firm.

[Table 3] It is clear from the results of above table that the average collection period is positively associated with the return on equity but it is not significantly linked with the return on equity. It means average collection period crucial and has an impact on the performance of the organizations.

[Table 4] Results of the above mentioned table have shown a positive but insignificant link between the operating cycle and

\begin{tabular}{|c|c|c|c|c|c|c|}
\hline Variables & ROE $_{\text {it }}$ & $\mathrm{ACP}_{\text {it }}$ & SIZE $_{\text {it }}$ & $\mathbf{L E V}_{\text {it }}$ & $\mathrm{CCC}_{\text {it }}$ & $O C_{i t}$ \\
\hline$R O E_{i t}$ & 1 & 0.0069 & 0.0752 & -0.1254 & 0.1684 & -0.0245 \\
\hline$A C P_{i t}$ & 0.0069 & 1 & -0.4484 & 0.1174 & 0.2729 & 0.4134 \\
\hline$S I Z E_{i t}$ & 0.0752 & -0.4484 & 1 & 0.0293 & -0.4124 & -0.3342 \\
\hline$L E V_{i t}$ & -0.1254 & 0.1174 & 0.0293 & 1 & -0.2154 & -0.0602 \\
\hline$C C C_{i t}$ & 0.1684 & 0.2729 & -0.4124 & -0.2154 & 1 & -0.5241 \\
\hline$O C_{i t}$ & -0.0245 & 0.4134 & -0.3342 & -0.0602 & 0.5241 & 1 \\
\hline
\end{tabular}
return on equity which shows its importance in the measurement of the organizational performance.

[Table 5] Results of the above table explores that cash conversion cycle has a positive and significant linkage with the return on equity in the textile sector of Pakistan. 
Table 3: Average Collection Period on Profitability (ROE)

\begin{tabular}{|c|c|c|c|c|}
\hline Variable & Coefficient & Std. Error & t-Statistics & Prob. \\
\hline$C$ & -0.0754 & 0.2153 & -0.3652 & 0.6784 \\
\hline$A C P_{i t}$ & 0.001 & 0.001 & 1.0039 & 0.2982 \\
\hline$S I Z E_{i t}$ & 0.0221 & 0.0129 & 1.4983 & 0.1049 \\
\hline$L E V_{i t}$ & -0.2043 & 0.1147 & -1.9648 & 0.0471 \\
\hline$R^{2}$ & 0.0314 & & & \\
\hline Adjusted R2 & 0.0149 & Mean dependent var. & & 0.1651 \\
\hline S.E regression & 0.2641 & S.D. dependent var. & & 0.2642 \\
\hline F-statistics & 1.9754 & Probability (F-statistic) & & 0.1071 \\
\hline
\end{tabular}

Table 4: Operating Cycle and Profitability (ROE)

\begin{tabular}{|c|c|c|c|c|}
\hline Variable & Coefficient & Std. Error & t-Statistics & Prob. \\
\hline $\boldsymbol{C}$ & 0.0078 & 0.2284 & 0.0354 & 0.9604 \\
\hline $\boldsymbol{O C}_{\boldsymbol{i t}}$ & $6.02 \mathrm{E}-05$ & 0.0002 & 2.7465 & 0.8541 \\
\hline $\boldsymbol{S I Z E}_{\boldsymbol{i t}}$ & 0.0149 & 0.0125 & 1.2342 & 0.2058 \\
\hline $\boldsymbol{L E V}_{\boldsymbol{i t}}$ & -0.2009 & 0.1154 & -1.8472 & 0.0569 \\
\hline $\boldsymbol{R}^{2}$ & 0.0257 & & & 0.1547 \\
\hline Adjusted $\boldsymbol{R} \boldsymbol{S}$ & 0.0112 & Mean dependent var. & & 0.2623 \\
\hline S.E regression & 0.2542 & S.D. dependent var. & & 0.171 \\
\hline F-statistics & 1.4872 & Probability (F-statistic) & & \\
\hline
\end{tabular}

Table 5: Cash Conversion Cycle on Profitability (ROE)

\begin{tabular}{|c|c|c|c|c|}
\hline Variable & Coefficient & Std. Error & t-Statistics & Prob. \\
\hline $\boldsymbol{C}$ & -0.2296 & 0.2184 & -1.0821 & 0.2644 \\
\hline $\boldsymbol{C C C}_{i t}$ & $1.00 \mathrm{E}-04$ & $9.86 \mathrm{E}-05$ & 2.7841 & 0.0041 \\
\hline $\boldsymbol{S I Z E}_{i t}$ & 0.0289 & 0.0115 & 2.3954 & 0.0164 \\
\hline $\boldsymbol{L E V}_{i t}$ & -0.1148 & 0.1184 & -1.1199 & 0.2508 \\
\hline $\boldsymbol{R}^{\boldsymbol{2}}$ & 0.0597 & & & 0.1628 \\
\hline Adjusted $\boldsymbol{R} \boldsymbol{}_{\text {S.E } \text { regression }}$ & 0.0529 & Mean dependent var. & & 0.2778 \\
\hline F-statistics & 0.2549 & S.D. dependent var. & & 0.0043 \\
\hline
\end{tabular}

\section{Control Variables on Profitability (ROE):}

Leverage and size of the organizations are the controlled variables of the data and it is obvious that leverages are the borrowings and debts of the organizations therefore they are negatively associated with the return on equity in the textile sector of Pakistan. Organizations should work to reduce their leverages to reduce their negative impact on the profitability of the organization. Size of the organizations are positively associated with the organizational performance.

\section{Conclusion}

Findings of the research explored that working capital of the organizations have a significant impact on the performance of the organizations in the textile sector of Pakistan. Average collection period, cash conversion cycle and operating cycle are positively associated with the performance of the organizations which means that they are affecting the profitability of the organizations significantly.

Management of the organizations should realize the importance of the working capital and they must manage their working capital efficiently and effectively. Size of the organizations also impact the performance of the organizations therefore management should take great care while making strategies and developing policies regarding management of the working capital of the organizations. This research study has focused on the textile sector of Pakistan whereas other sectors can be handed in future. The results are based on the five year data (2008-2012) available in the annual reports and websites whereas in future data of more years can be utilized for better understanding. 


\section{References}

1. Akinlo. The Effect of Working Capital on Profitability of Firms in Nigeria: Evidence from General Method of Moments (GMM). Asian Journal of Business and Management Sciences. 2011;1(2):130-135.

2. Ali S. Working Capital Management and the Profitability of the Manufacturing Sector: A case study of Pakistan's Textile Industry. The Lahore Journal of Economics. 2011;16(2):141-178.

3. Belt B. Working Capital Policy and Liquidity in Small Business. Journal of Small Business Management. 1979;17(3):43-51.

4. Bieniasz A, Golas Z. The Influence of Working Capital Management on the Food Industry Enterprises Profitability. Journal of Contemporary Economics. 2011;5(4):68-81.

5. Deloof M. Does Working Capital Management Affect Profitability of Belgian Firms. Journal of Business Finance and Accounting. 2003;30(3,4):573-587.

6. Eljelly AM. Liquidity-Profitability Tradeoff: An Empirical Investigation in an Emerging Market. IJCM. 2004;14(2):48-61. doi:10.1108/10569210480000179
7. Mathuva DM. Influence of Working Capital Management Components on Corporate Profitability: A Survey on Kenyan Listed Firms. Research Journal of Business Management. 2010;4(1):1-11. doi:10.3923/rjbm.2010.1.11

8. Napompech K. Effects of Working Capital Management on the Profitability of Thai Listed Firms. International Journal of Trade, Economics and Finance. 2012;3(3):227-232.

9. Padachi K. Trends in Working Capital Management and its Impact on Firms' Performance: An Analysis of Mauritian Small Manufacturing Firms. International Review of Business Research Papers. 2006;2(2):45-58.

10. Sharma AK, Kumar S. Effect of Working Capital Management on Firm Profitabiltiy: Empirical Evidence from India. Global Business Review. 2011;12(1):159-173.doi:10.1177/097215091001200110 